\title{
Effect of Batch Annealing Temperature on Microstructure and Resistance to Fish Scaling of Ultra-Low Carbon Enamel Steel
}

\author{
Zaiwang Liu ${ }^{1,2}$, Yonglin Kang ${ }^{1, *}$, Zhimin Zhang ${ }^{2}$ and Xiaojing Shao ${ }^{2}$ \\ 1 School of Materials Science and Engineering, University of Science and Technology Beijing, \\ Beijing 100083, China; lzwbeijing2007@163.com \\ 2 Shougang Research Institute of Technology, Beijing 100043, China; 2001zhimin@163.com (Z.Z.); \\ shaoxiaojing@shougang.com.cn (X.S.) \\ * Correspondence: kangylin@ustb.edu.cn; Tel.: +86-10-6233-2983
}

Academic Editor: Hugo F. Lopez

Received: 16 November 2016; Accepted: 20 January 2017; Published: 9 February 2017

\begin{abstract}
In the present work, an ultra-low carbon enamel steel was batch annealed at different temperatures, and the effect of the batch annealing temperature on the microstructure and resistance to fish scaling was investigated by optical microscopy, transmission electron microscopy, and a hydrogen permeation test. The results show that the main precipitates in experimental steel are fine TiC and coarse $\mathrm{Ti}_{4} \mathrm{C}_{2} \mathrm{~S}_{2}$ particles. The average sizes of both $\mathrm{TiC}$ and $\mathrm{Ti}_{4} \mathrm{C}_{2} \mathrm{~S}_{2}$ increase with increasing the batch annealing temperature. The resistance to fish scaling decreases with increasing the annealing temperature, which is caused by the growth of ferrite grain and the coarsening of the $\mathrm{TiC}$ and $\mathrm{Ti}_{4} \mathrm{C}_{2} \mathrm{~S}_{2}$ particles.
\end{abstract}

Keywords: ultra-low carbon enamel steel; batch annealing temperature; microstructure; resistance to fish scaling; hydrogen permeation test

\section{Introduction}

Ultra-low carbon steels were produced to enamel products, such as bathtubs, kitchen utensils, and decorative panels due to their extraordinary deep drawability [1,2]. Enamel coatings have been widely applied for the protection of steel products due to their excellent engineering properties, such as corrosion protection, resistance to heat and abrasion, hygiene and ease of cleaning [3]. Fish scaling is one of the most dangerous defects in the production of enameled steel products. Studies have found that it is hydrogen which plays a key role in the formation of the fish scaling. The resistance to fish scaling of enamel steel is usually evaluated by the hydrogen permeation test, and the hydrogen permeation value ( $\mathrm{TH}$ value) is an important parameter characterizing the resistance to fish scaling. High $T H$ value means good resistance to fish scaling. $T H$ value should be larger than $6.7 \mathrm{~min} / \mathrm{mm}^{2}$ to ensure satisfactory resistance to fish scaling [4].

The resistance to fish scaling can be improved by increasing the number of hydrogen traps. Hydrogen traps are generally classified as reversible and irreversible traps depending on their binding energy with hydrogen atoms [5,6]. A reversible trap is one from which a hydrogen atom can easily jump out of due to fluctuations in thermal energy [7]. It is known that grain boundaries, dislocations, vacancies, and microvoids have low binding energy with hydrogen atoms and are considered as reversible traps. Hydrogen atoms in these sites are diffusible, and these traps have an influence on the effective hydrogen diffusivity. Irreversible traps are sites with high binding energy, and thus the trapped hydrogen is considered as non-diffusible [8]. ( $\mathrm{Ti}, \mathrm{Nb})(\mathrm{C}, \mathrm{N}), \mathrm{TiC}, \mathrm{TiN}, \mathrm{NbC}, \mathrm{VC}$ and non-metallic inclusions are considered as irreversible traps because of their high binding energy.

$\mathrm{Ti}$ is usually added to ultra-low carbon steel to improve the resistance to fish scaling. The main irreversible hydrogen traps in ultra-low carbon Ti-bearing steel are TiN, TiC, TiS and $\mathrm{Ti}_{4} \mathrm{C}_{2} \mathrm{~S}_{2}$ 
particles which influence hydrogen diffusivity obviously [2]. There are several factors which affect the precipitation behavior of titanium precipitates, i.e., chemical composition, finishing temperature, coiling temperature, annealing temperature and so on. It is reported that $\mathrm{Ti}$ and $\mathrm{S}$ content will affect the type and fraction of precipitates [9]. Mo can also influence the precipitation behavior of TiC particles [10]. It was found that low finishing temperature was beneficial to the occurrence of strain-induced precipitation of $\mathrm{TiC}$ [11]. Kim et al. [12] and $\mathrm{Xu}$ et al. [13] found that interphase precipitation took place at high coiling temperature, while dispersed precipitation was formed at low coiling temperature. The annealing temperature will influence the size, distribution and number of precipitates $[14,15]$. The characteristics of precipitates will influence their binding energy and hydrogen storage capacity, so the annealing temperature will affect the resistance to fish scaling of Ti-bearing steel. Much is still unknown about the effect of batch annealing temperature on microstructure and resistance to fish scaling of ultra-low carbon Ti-bearing enamel steel. It is essential to perform relevant research work to promote the application of ultra-low carbon Ti-bearing enamel steel.

\section{Materials and Methods}

The experimental steel used in this study was produced by Shougang Group, and the chemical composition is listed in Table 1 . The slab was reheated to $1250^{\circ} \mathrm{C}$ for $2 \mathrm{~h}$, and then hot rolled to a sheet of $5 \mathrm{~mm}$ at finishing temperature of $900{ }^{\circ} \mathrm{C}$. The sheet was water cooled to coiling temperature of $700{ }^{\circ} \mathrm{C}$. After acid pickling, the sheet was cold rolled to $0.8 \mathrm{~mm}$ in thickness. The cold rolled sheets were batch annealed at $580,630,680$, and $730^{\circ} \mathrm{C}$ for $5 \mathrm{~h}$, and the schematic of the batch annealing process is shown in Figure 1. These batch annealing temperatures were chosen to obtain different sized ferrite grains and precipitates, so the effects of ferrite grain boundaries and precipitates on resistance to fish scaling can be investigated by a hydrogen permeation test.

Table 1. Chemical composition of experimental steel (in wt \%).

\begin{tabular}{ccccccc}
\hline $\mathbf{C}$ & Si & Mn & P & S & Alt & Ti \\
\hline$\leq 0.005$ & $\leq 0.05$ & $0.12-0.25$ & $\leq 0.02$ & $\leq 0.05$ & $\leq 0.05$ & $0.05-0.12$ \\
\hline
\end{tabular}

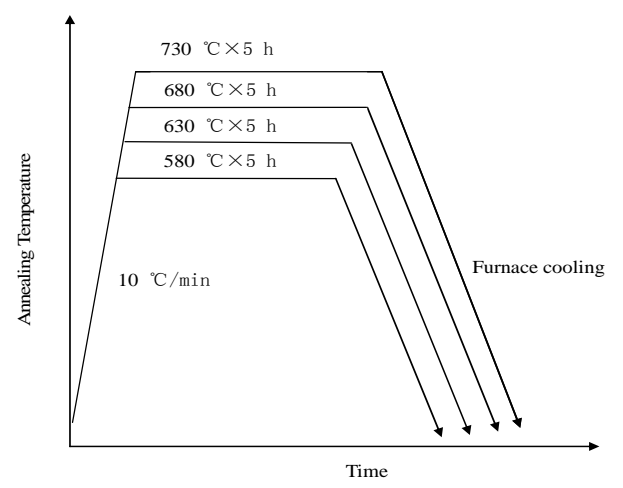

Figure 1. Schematic of the batch annealing process of ultra-low carbon enamel steel.

The metallographic specimens and tensile specimens were cut along the transverse direction. Microstructure observations were conducted on an optical microscope (Leica, Wetzlar, Hesse, Germany). The precipitates in specimens were extracted on carbon replicas and examined byTecnai $G^{2}$ F20 transmission electron microscope (TEM) (FEI, Houston, TX, USA) with an energy dispersive spectrometer (EDS). The dog-bone tensile specimens have $12.5 \mathrm{~mm}$ width and $80 \mathrm{~mm}$ gauge length. A tensile test was performed on a computer material test (CMT) 5105 testing machine (MTS, Shenzhen, Guangdong, China) at room temperature, and the crosshead speed was $3 \mathrm{~mm} / \mathrm{min}$.

The hydrogen permeation specimens with $50 \mathrm{~mm} \times 80 \mathrm{~mm} \times 0.8 \mathrm{~mm}$ were prepared. Both sides of the specimens were ground by 1200 grit abrasive paper, and then the specimens were washed 
by acetone and rinsed by distilled water. The hydrogen permeation test was conducted at room temperature on a Devanathan-Stachursky type cell [16]. The hydrogen permeation setup was composed of two parts separated by the specimen into the cathodic cell and anodic cell. The anodic cell was filled with $0.2 \mathrm{~N} \mathrm{NaOH}$ solution, and a constant anodic potential $200 \mathrm{mV}$ was applied. Once the background current was less than $0.1 \mu \mathrm{A} / \mathrm{cm}^{2}$, the hydrogen permeation test was started [17], and the cathodic cell was filled with $0.5 \mathrm{~N} \mathrm{H}_{2} \mathrm{SO}_{4}+0.22 \mathrm{~g} / \mathrm{L} \mathrm{H}_{2} \mathrm{NCSNH}_{2}$ solution immediately. The charging current density was maintained at $1 \mathrm{~mA} / \mathrm{cm}^{2}$, which was low enough to avoid damage to the steel sheet. In the test, hydrogen is produced electrolytically in the charging cell by cathodic polarization [18]. $\mathrm{H}_{2} \mathrm{NCSNH}_{2}$ facilitated hydrogen pick-up by promoting the breakdown of molecular hydrogen. High-purity nitrogen gas was purged prior to cathodic polarization and during the entire test to remove the dissolved oxygen which would contribute to the anodic current [19]. The measured anodic current was proportional to the hydrogen flow rate out of the specimen [20], and it was recorded by using an automatic data-acquisition system. Once the measured anodic current reached a steady-state, the hydrogen permeation test can be finished.

The hydrogen permeation time $\left(t_{\mathrm{b}}\right)$ was determined by plotting the cumulative anodic current through the specimen and extrapolating its asymptote to intercept with the horizontal axis [21]. The hydrogen permeation value can be calculated by the following formula:

$$
T H=t_{\mathrm{b}} / d^{2}
$$

where $T H$ is the hydrogen permeation value, $t_{\mathrm{b}}$ is the hydrogen permeation time in minutes, $d$ is the sheet thickness in $\mathrm{mm}$.

\section{Results and Discussion}

\subsection{Microstructure}

The optical micrographs of experimental steel batch annealed at different temperatures are presented in Figure 2. As can be seen in Figure 2a, the shear bands (indicated by arrows) along the rolling direction and small recrystallized grains were observed at a batch annealing temperature of $580^{\circ} \mathrm{C}$, which reveals that partial recrystallization has occurred at this temperature. At an annealing temperature of $580^{\circ} \mathrm{C}$, there are a large number of dislocations in the shear bands due to the incomplete recrystallization. When the annealing temperature is higher than $630{ }^{\circ} \mathrm{C}$, the microstructures are equiaxed ferrite grains, which mean that full recrystallization has occurred in the annealing process.
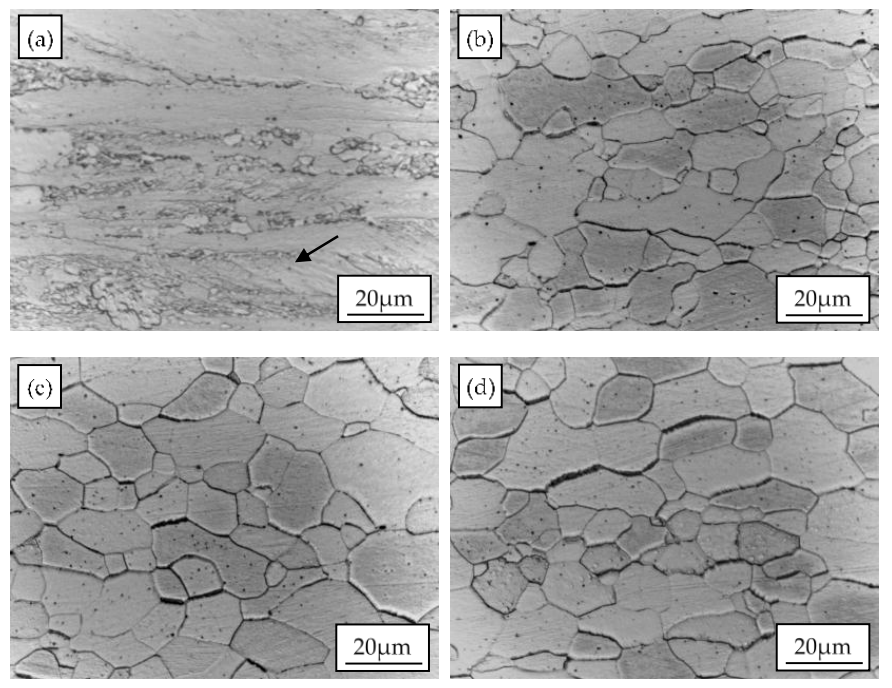

Figure 2. Optical micrographs of experimental steel batch annealed at different temperatures (a) $580{ }^{\circ} \mathrm{C}$; (b) $630{ }^{\circ} \mathrm{C}$; (c) $680{ }^{\circ} \mathrm{C}$; (d) $730{ }^{\circ} \mathrm{C}$. 
The average size of ferrite grain is measured by the line intercept method, and the effect of the batch annealing temperature on the average size of ferrite grain is shown in Figure 3. The average size of ferrite grain increased when the batch annealing temperature increased from 630 to $730{ }^{\circ} \mathrm{C}$. There is not a large number of dislocations in the specimens annealed at 630,680 and $730{ }^{\circ} \mathrm{C}$ due to the full recrystallization.

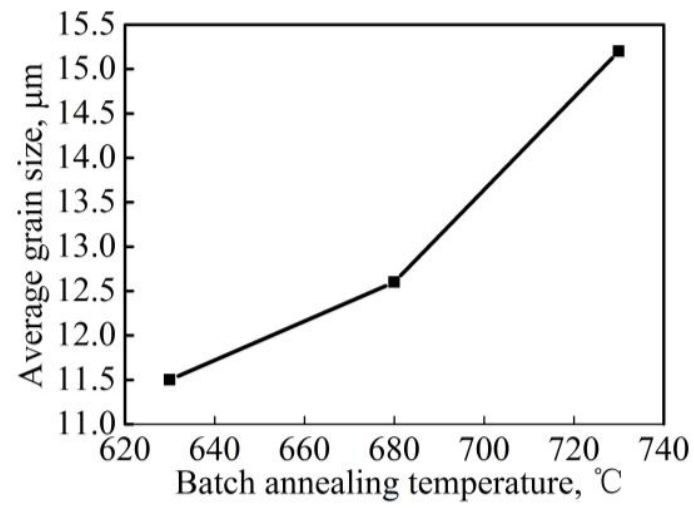

Figure 3. Effect of the batch annealing temperature on the average size of ferrite grain of ultra-low carbon enamel steel.

The precipitates of experimental steel annealed at different temperatures exhibit the same features by TEM observations. As shown in Figure 4, there are TiC, $\mathrm{TiN}$ and $\mathrm{Ti}_{4} \mathrm{C}_{2} \mathrm{~S}_{2}$ particles in all the specimens. Figure 4a shows typical TEM morphologies of TiN and TiC. A large cubic particle contains $\mathrm{Ti}, \mathrm{C}$ and $\mathrm{N}$ (as shown in Figure 4c), which indicates that the particle is TiN due to its coarse and cubic shape; the peak characteristic of the $C$ element can be ignored because of the carbon extraction replicas. Large TiN particles formed during the solidification process; they are rare in the specimens, and their sizes change a little at different annealing temperatures. A small sized elliptical particle contains Ti and $\mathrm{C}$ (as shown in Figure 4d), which is considered as TiC. In experimental steel, $\mathrm{TiC}$ is finer and has a denser distribution than TiN and $\mathrm{Ti}_{4} \mathrm{C}_{2} \mathrm{~S}_{2}$. The EDS spectrum of the particle in Figure $4 \mathrm{~b}$ shows that the atomic ratio of Ti to $\mathrm{S}$ is close to 2 (as shown in Figure 4e), and the particle can be identified as $\mathrm{Ti}_{4} \mathrm{C}_{2} \mathrm{~S}_{2}$ [9]. The distribution of $\mathrm{Ti}_{4} \mathrm{C}_{2} \mathrm{~S}_{2}$ is very inhomogeneous, often in the shape of strings or clusters (as shown in Figure 4b).

The chemical composition of ultra-low carbon enamel steel is similar to that of ultra-low carbon Ti-bearing steel, but the former contains higher Ti and $\mathrm{S}$ contents to ensure that sufficient $\mathrm{Ti}_{4} \mathrm{C}_{2} \mathrm{~S}_{2}$ particles can be formed [22]. TiS was not observed in all the specimens. Figure 5 is a schematic illustration of the stability of various Ti compounds in Interstitial-Free (IF) steels as a function of the precipitation temperature [23]. The stability of the precipitates mainly depends on the temperature and the chemical composition. After the formation of TiN, TiS precipitation is likely to take place. However, the stability of TiS is quite low, and TiS decomposes during hot rolling and the coiling process [23]. TiS may also change to $\mathrm{Ti}_{4} \mathrm{C}_{2} \mathrm{~S}_{2}$ during the annealing process [9,24]. Because TiN particles are large and rare, their influence on hydrogen diffusion behavior can be ignored, and the main irreversible hydrogen traps are fine $\mathrm{TiC}$ and coarse $\mathrm{Ti}_{4} \mathrm{C}_{2} \mathrm{~S}_{2}$. TiC and $\mathrm{Ti}_{4} \mathrm{C}_{2} \mathrm{~S}_{2}$ are both considered as precipitating in the batch annealing process [25]. The effect of batch annealing temperature on average sizes of $\mathrm{TiC}_{\text {and }} \mathrm{Ti}_{4} \mathrm{C}_{2} \mathrm{~S}_{2}$ particles is shown in Figure 6. It can be seen that the average sizes of $\mathrm{TiC}$ and $\mathrm{Ti}_{4} \mathrm{C}_{2} \mathrm{~S}_{2}$ particles increased with increasing the batch annealing temperature, which means that $\mathrm{TiC}$ and $\mathrm{Ti}_{4} \mathrm{C}_{2} \mathrm{~S}_{2}$ particles coarsened in the annealing process. 

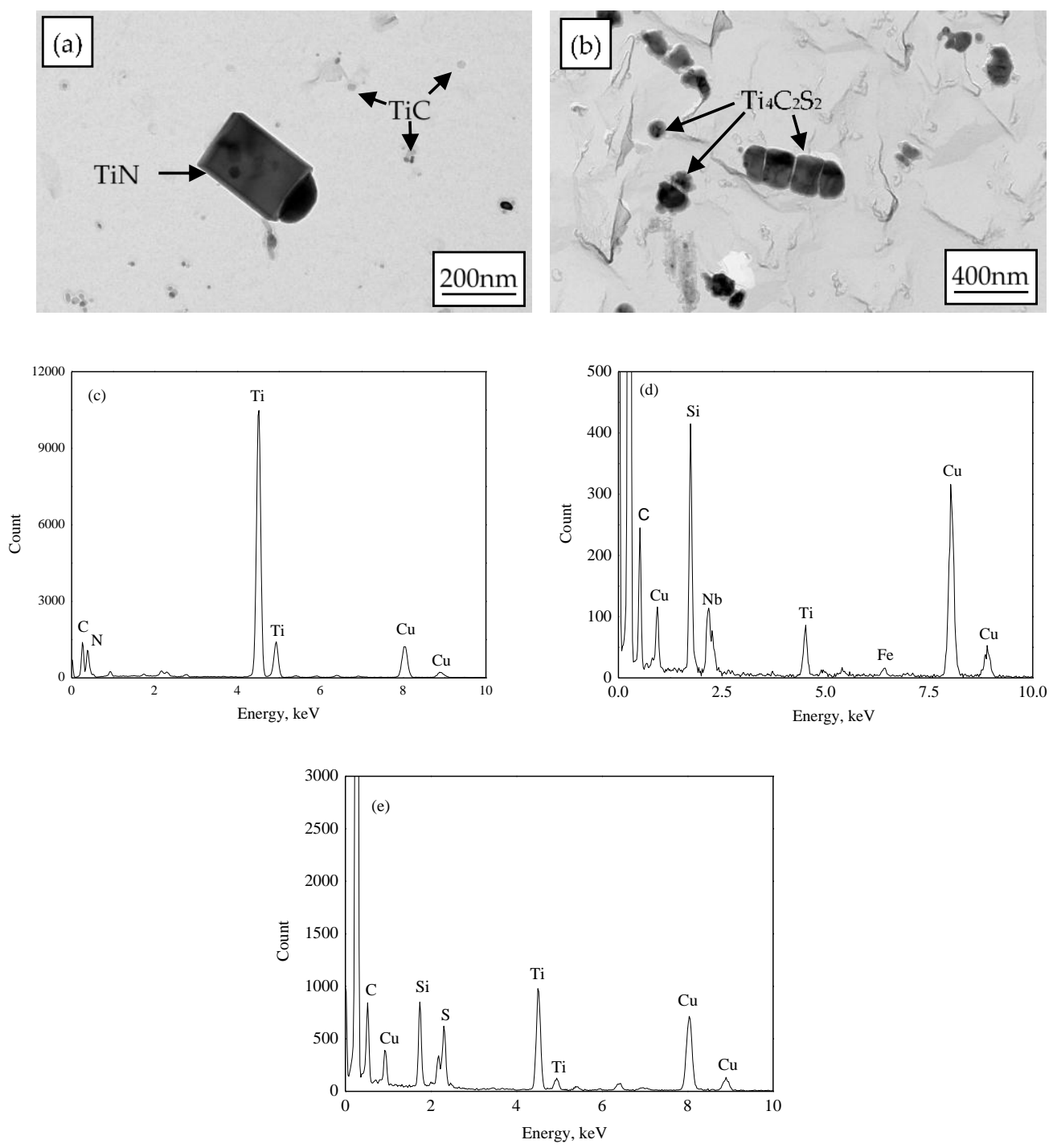

Figure 4. Transmission electron microscope (TEM) micrographs showing precipitates in experimental steel (a) TiN and TiC particles; (b) $\mathrm{Ti}_{4} \mathrm{C}_{2} \mathrm{~S}_{2}$ particles; (c) Energy dispersive spectrometer (EDS) spectrum of TiN; (d) EDS spectrum of TiC; (e) EDS spectrum of $\mathrm{Ti}_{4} \mathrm{C}_{2} \mathrm{~S}_{2}$.

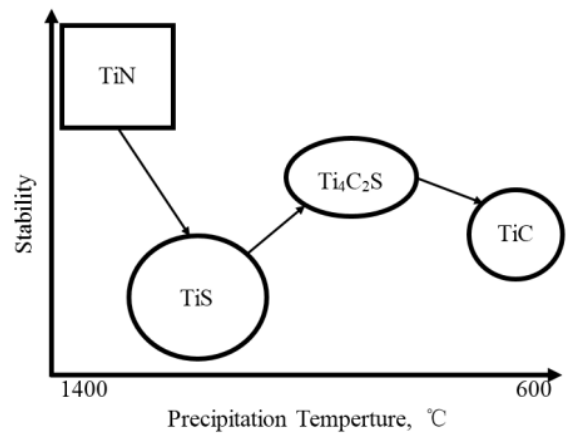

Figure 5. Schematic illustration of the stability of various Ti compounds in Interstitial-Free (IF) steels as a function of the precipitation temperature. 

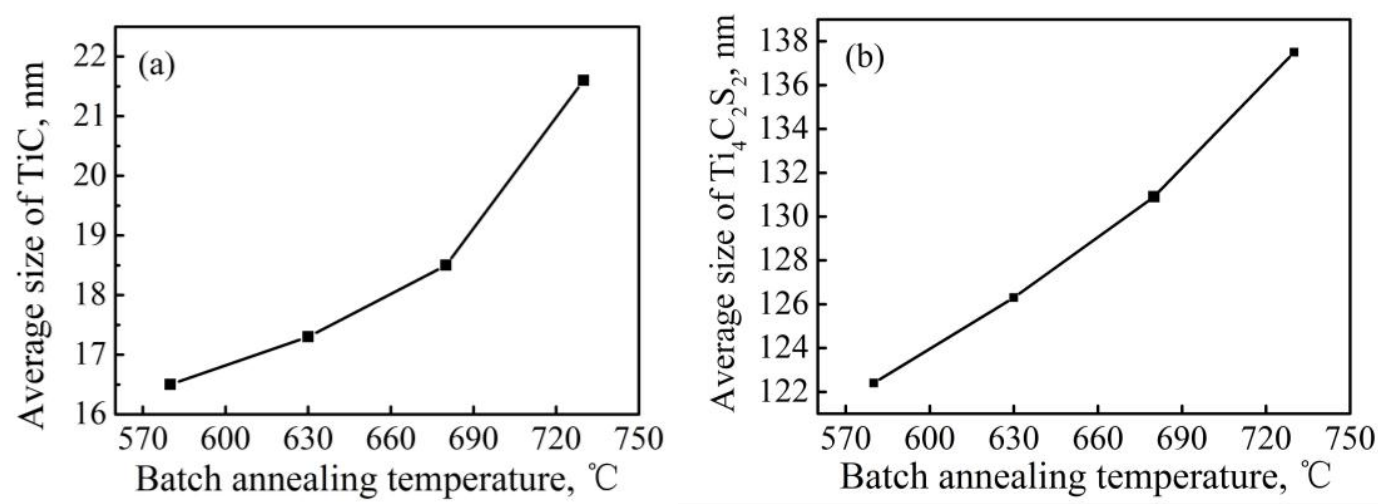

Figure 6. Effect of the batch annealing temperature on the average sizes of $\mathrm{TiC}(\mathbf{a})$ and $\mathrm{Ti}_{4} \mathrm{C}_{2} \mathrm{~S}_{2}(\mathbf{b})$.

\subsection{Mechanical Properties and Resistance to Fish Scaling}

The relationship between the mechanical properties and batch annealing temperature of ultra-low carbon enamel steel is shown in Figure 7. At the annealing temperature of $580^{\circ} \mathrm{C}$, the yield strength and tensile strength are obviously higher than those of experimental steel annealed at other temperatures; this is because of the incomplete recrystallization at $580^{\circ} \mathrm{C}$. At annealing temperatures of 630,680 , and $730{ }^{\circ} \mathrm{C}$, the yield strength, tensile strength, elongation, $n$-value and $r$-value do not vary very much. That is to say, the mechanical properties of experimental steel change a little when recrystallization has finished.
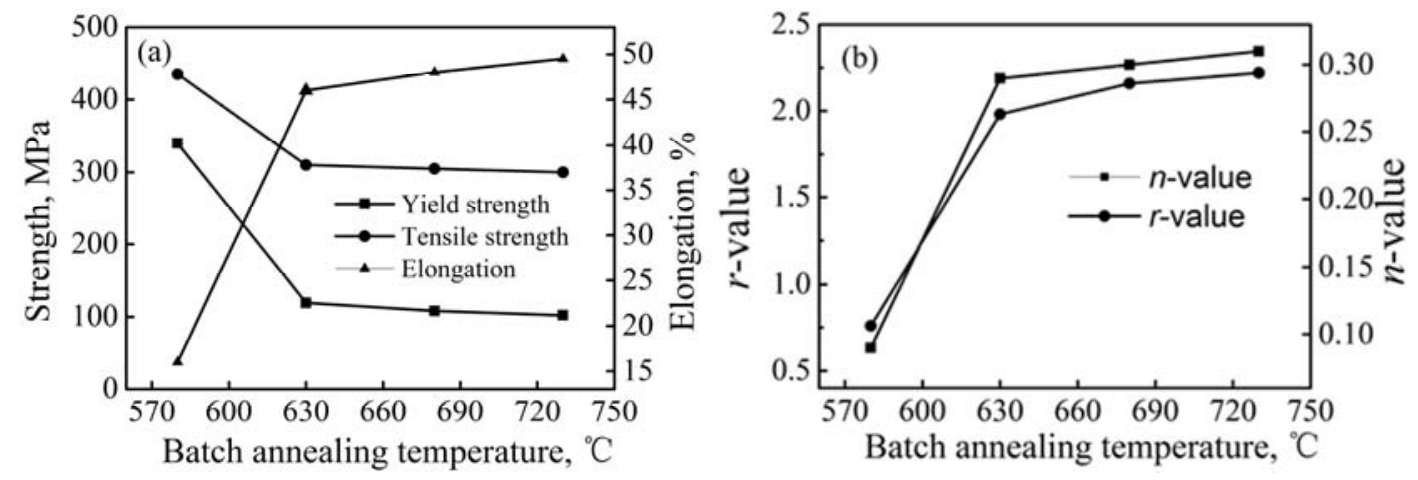

Figure 7. Relationship between the mechanical properties and batch annealing temperature of ultra-low carbon enamel steel. (a) Strength and Elongtation; (b) $n$ and $r$ value

The hydrogen permeation curves (charge quantity vs. time curves) are shown in Figure 8 . The TH values of experimental steel annealed at 580, 630, 680 and $730{ }^{\circ} \mathrm{C}$ are calculated to be $30.0 \pm 3.4$, $18.6 \pm 1.1,13.5 \pm 1.7$ and $10.4 \pm 1.6 \mathrm{~min} / \mathrm{mm}^{2}$, respectively. As shown in Figure 9, the $T H$ value decreases with increasing batch annealing temperature.

The $T H$ value is related to the hydrogen diffusion coefficient; high $T H$ value means low hydrogen diffusivity. Both reversible traps and irreversible traps can reduce the hydrogen diffusion coefficient. At annealing temperatures of 630,680 and $730{ }^{\circ} \mathrm{C}$, there are a few dislocations in the specimen due to the recrystallization, so the main reversible hydrogen traps are ferrite grain boundaries, while the main irreversible hydrogen traps are $\mathrm{TiC}$ and $\mathrm{Ti}_{4} \mathrm{C}_{2} \mathrm{~S}_{2}$ particles. With the annealing temperature increasing, the average size of ferrite grain and the mean sizes of $\mathrm{TiC}_{1}$ and $\mathrm{Ti}_{4} \mathrm{C}_{2} \mathrm{~S}_{2}$ particles increase. The ferrite grain boundary is a kind of reversible trap; it traps hydrogen atoms in the hydrogen charging process and contributes significantly to hydrogen trapping ( $T H$ value) $[26,27]$. The hydrogen storage capacity of the grain boundaries is generally proportional to the grain boundary area [28]. The growth of ferrite grain leads to the reduction of the grain boundary area, which is one reason for the reduction 
of the resistance to fish scaling. Takahashi et al. [29] have observed the hydrogen trapping sites of nano-sized TiC by using three dimensional atom probe (3DAP) for the first time. They revealed that the broad interface between the matrix and $\mathrm{TiC}$ was the main trapping site. Wei et al. [30] found that incoherent $\mathrm{TiC}$ particles have higher binding energy than that of coherent $\mathrm{TiC}$ particles, but they are not able to trap hydrogen during cathodic charging at room temperature due to its high energy barrier for trapping. Small $\mathrm{TiC}$ and $\mathrm{Ti}_{4} \mathrm{C}_{2} \mathrm{~S}_{2}$ particles at low annealing temperature have more interfaces, which will result in the decrease of hydrogen diffusivity. The coarsening of precipitates is the other reason for the reduction of resistance to fish scaling. Yuan [2] also indicated that small precipitates can lead to low hydrogen diffusivity. Because irreversible traps always lead to a great decrease in hydrogen diffusivity [31], a great number of small precipitates are favorable to the enhancement of the resistance to fish scaling of enamel steel.
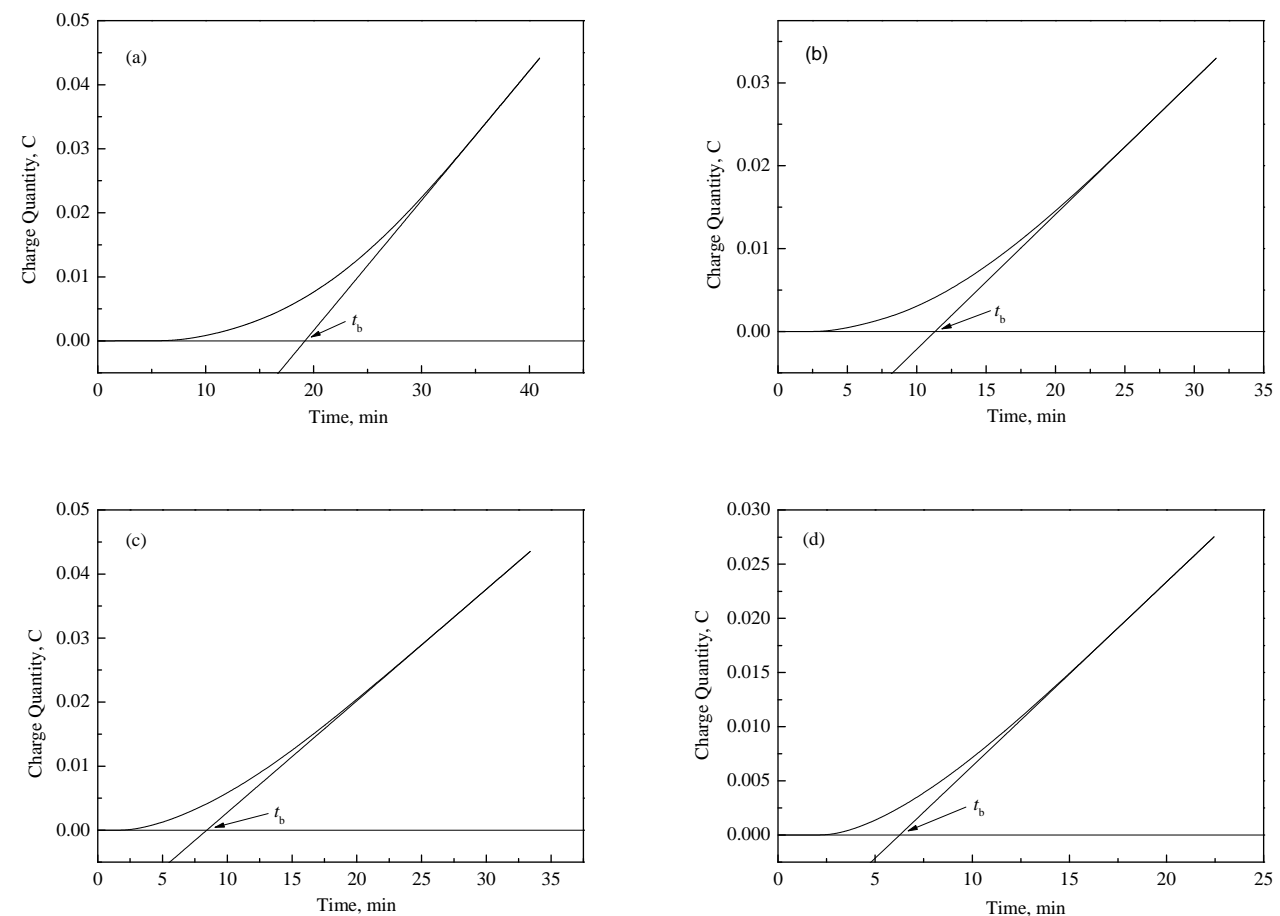

Figure 8. Hydrogen permeation curves (charge quantity vs. time curves) of ultra-low carbon enamel steel annealed at different temperatures (a) $580{ }^{\circ} \mathrm{C}$; (b) $630{ }^{\circ} \mathrm{C}$; (c) $680{ }^{\circ} \mathrm{C}$; (d) $730{ }^{\circ} \mathrm{C}$.

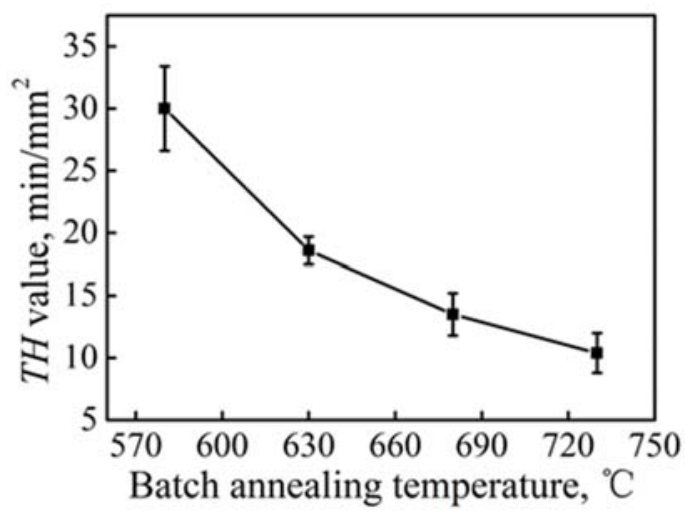

Figure 9. Effect of the batch annealing temperature on the $T H$ value of ultra-low carbon enamel steel.

At an annealing temperature of $580^{\circ} \mathrm{C}$, there are much more dislocations and grain boundaries in the specimen due to the incomplete recrystallization. Dislocation is another kind of reversible 
trap, and it can reduce the hydrogen diffusion coefficient of steel [32]. The decrease of the hydrogen diffusion coefficient means the increase of the $\mathrm{TH}$ value. More dislocations can lead to higher $\mathrm{TH}$ value. The presence of a large number of dislocations is the reason why the TH value is higher than those of experimental steel annealed at other temperatures.

\section{Conclusions}

(1) The main irreversible hydrogen traps of ultra-low carbon enamel steel are fine TiC and coarse $\mathrm{Ti}_{4} \mathrm{C}_{2} \mathrm{~S}_{2}$ particles. The reversible hydrogen traps are grain boundaries and dislocations. The mean sizes of $\mathrm{TiC}$ and $\mathrm{Ti}_{4} \mathrm{C}_{2} \mathrm{~S}_{2}$ particles increase with increasing the batch annealing temperature.

(2) Both reversible and irreversible traps will influence the resistance to fish scaling. The resistance to fish scaling can be enhanced with increasing the number of reversible and irreversible traps. The resistance to fish scaling decreases with increasing the batch annealing temperature, which is caused by the growth of ferrite grain and the coarsening of $\mathrm{TiC}$ and $\mathrm{Ti}_{4} \mathrm{C}_{2} \mathrm{~S}_{2}$ particles.

Author Contributions: Zaiwang Liu analyzed the experimental data and wrote the manuscript. Yonglin Kang conceived and designed the experiments. Zhimin Zhang and Xiaojing Shao performed the experimental work. All authors have participated in the discussion of results.

Conflicts of Interest: The authors declare no conflict of interest.

\section{References}

1. Dong, F.T.; Du, L.X.; Liu, X.H.; Hu, J.; Xue, F. Effect of Ti(C, N) precipitation on texture evolution and fish-scale resistance of ultra-low carbon Ti bearing enamel steel. J. Iron Steel Res. Int. 2013, 20, $39-45$. [CrossRef]

2. Yuan, X. Precipitates and hydrogen permeation behavior in ultra-low carbon steel. Mater. Sci. Eng. A 2007, 452, 116-120. [CrossRef]

3. Son, Y.K.; Lee, C.J.; Lee, J.M.; Kim, B.M. Deformation prediction of porcelain-enameled steels with strain history by press forming and high-temperature behavior of coating layer. Trans. Nonferr. Met. Soc. China 2012, 22, s838-s844. [CrossRef]

4. Okuyamas, T.; Nishimoto, A.; Kurokawa, T. New type cold rolled steel sheet for enamelling produced by the continuous casting method. Vitreous Enamel. 1990, 41, 49-60.

5. Mohtadi-Bonab, M.A.; Szpunar, J.A.; Collins, L.; Stankievech, R. Evaluation of hydrogen induced cracking behavior of API X70 pipeline steel at different heat treatments. Int. J. Hydrog. Energy 2014, 39, 6076-6088. [CrossRef]

6. Krom, A.H.; Bakker, A. Hydrogen trapping models in steel. Metall. Mater. Trans. B 2000, 31, $1475-1482$. [CrossRef]

7. Liu, Q.; Atrens, A. Reversible hydrogen trapping in a 3.5NiCrMoV medium strength steel. Corros. Sci. 2015, 96, 112-120. [CrossRef]

8. Liu, Q.L.; Venezuela, J.; Zhang, M.X.; Zhou, Q.J.; Atrens, A. Hydrogen trapping in some advanced high strength steels. Corros. Sci. 2016, 111, 770-785. [CrossRef]

9. Hua, M.; Garcia, C.I.; Eloot, K.; DeArdo, A.J. Identification of Ti-S-C-containing multi-phase precipitates in ultra-low carbon steels by analytical electron microscopy. ISIJ Int. 1997, 37, 1129-1132. [CrossRef]

10. Funakawa, Y.; Shiozaki, T.; Tomita, K.; Yamamoto, T.; Maeda, E. Development of high strength hot-rolled sheet steel consisting of ferrite and nanometer-sized carbides. ISIJ Int. 2004, 44, 1945-1951. [CrossRef]

11. Huo, X.; Li, L.; Peng, Z.; Chen, S. Effect of TMCP schedule on precipitation, microstructure and properties of Ti-microalloyed high strength steel. J. Iron Steel Res. Int. 2016, 23, 593-601. [CrossRef]

12. Kim, Y.W.; Song, S.W.; Seo, S.J.; Hong, S.; Lee, C.S. Development of Ti and Mo micro-alloyed hot-rolled high strength sheet steel by controlling thermomechanical controlled processing schedule. Mater. Sci. Eng. A 2013, 565, 430-438. [CrossRef]

13. Xu, Y.; Zhang, W.; Sun, M.; Yi, H.; Liu, Z. The blocking effects of interphase precipitation on dislocations' movement in Ti-bearing micro-alloyed steels. Mater. Lett. 2015, 139, 177-181. [CrossRef]

14. Shi, J.; Wang, X. Comparison of precipitate behaviors in ultra-low carbon, titanium-stabilized interstitial free steel sheets under different annealing processes. J. Mater. Eng. Perform. 1999, 8, 641-648. [CrossRef] 
15. Ghosh, P.; Ghosh, C.; Ray, R.K.; Bhattcharjee, D. Precipitation behavior and texture formation at different stages of processing in an interstitial free high strength steel. Scr. Mater. 2008, 59, 276-278. [CrossRef]

16. Devanathan, M.A.V.; Stachurski, Z. The mechanism of hydrogen evolution on iron in acid solutions by determination of permeation rates. J. Electrochem. Soc. 1964, 111, 619-623. [CrossRef]

17. International Organization for Standardization. Method of Measure of Hydrogen Permeation and Determination of Hydrogen Uptake and Transport in Metals by an Electrochemical Technique; ISO: Geneva, Switzerland, 2004.

18. Mohtadi-Bonab, M.A.; Szpunar, J.A.; Razavi-Tousi, S.S. A comparative study of hydrogen induced cracking behavior in API 5L X60 and X70 pipeline steels. Eng. Fail. Anal. 2013, 33, 163-175. [CrossRef]

19. Mohtadi-Bonab, M.A.; Karimdadashi, R.; Eskandari, M.; Szpunar, J.A. Hydrogen-induced cracking assessment in pipeline steels through permeation and crystallographic texture measurements. J. Mater. Eng. Perform. 2016, 25, 1781-1793. [CrossRef]

20. Haq, A.J.; Muzaka, K.; Dunne, D.P.; Calka, A.; Pereloma, E.V. Effect of microstructure and composition on hydrogen permeation in X70 pipeline steels. Int. J. Hydroen Energy 2013, 38, 2544-2556. [CrossRef]

21. Winzer, N.; Rott, O.; Thiessen, R.; Thomas, I.; Mraczek, K.; Höche, T.; Wright, L.; Mrovec, M. Hydrogen diffusion and trapping in Ti-modified advanced high strength steels. Mater. Des. 2016, 92, 450-461. [CrossRef]

22. Yoshinaga, N.; Ushioda, K.; Akamatsu, S.; Akisue, O. Precipitation behavior of sulfides in Ti-added ultra low-carbon steels in austenite. ISIJ Int. 1994, 34, 24-32. [CrossRef]

23. Ghosh, P.; Ghosh, C.; Ray, R.K. Thermodynamics of precipitation and textural development in batch-annealed interstitial-free high-strength steels. Acta Mater. 2010, 58, 3842-3850. [CrossRef]

24. Hua, M.; Garcia, C.I.; DeArdo, A.J. Multi-phase precipitates in interstitial-free steels. Scr. Metall. Mater. 1993, 28, 973-978. [CrossRef]

25. Carabajar, S.; Merlin, J.; Massardier, V.; Chabanet, S. Precipitation evolution during the annealing of an interstitial-free steel. Mater. Sci. Eng. A 2000, 281, 132-142. [CrossRef]

26. Ono, K.; Meshii, M. Hydrogen detrapping from grain boundaries and dislocations in high purity iron. Acta Metall. Mater. 1992, 40, 1357-1364. [CrossRef]

27. Choo, W.Y.; Lee, J.Y. Thermal analysis of trapped hydrogen in pure iron. Metall. Trans. A 1982, 13, $135-140$. [CrossRef]

28. Valentini, R.; Solina, A.; Matera, S.; de Gregorio, P. Influence of titanium and carbon contents on the hydrogen trapping of microalloyed steels. Metall. Mater. Trans. A 1996, 27, 3773-3780. [CrossRef]

29. Takahashi, J.; Kawakami, K.; Kobayashi, Y.; Tarui, T. The first direct observation of hydrogen trapping sites in TiC precipitation-hardening steel through atom probe tomography. Scr. Mater. 2010, 63, 261-264. [CrossRef]

30. Wei, F.G.; Tsuzaki, K. Quantitative analysis on hydrogen trapping of TiC particles in steel. Metall. Mater. Trans. A 2006, 37, 331-353. [CrossRef]

31. Pressouyre, G.M.; Bernstein, I.M. A quantitative analysis of hydrogen trapping. Metall. Trans. A 1978, 9, 1571-1580. [CrossRef]

32. Jebaraj, J.J.M.; Morrison, D.J.; Suni, I.I. Hydrogen diffusion coefficients through Inconel 718 in different metallurgical conditions. Corros. Sci. 2014, 80, 517-522. [CrossRef]

(c) 2017 by the authors; licensee MDPI, Basel, Switzerland. This article is an open access article distributed under the terms and conditions of the Creative Commons Attribution (CC BY) license (http:/ / creativecommons.org/licenses/by/4.0/). 